\title{
GENETIC CHARACTERIZATION OF VARIANT INFECTIOUS BRONCHITIS VIRUSES DETECTED IN BROILER CHICKENS IN SOUTH EGYPT
}

\author{
MOHAMED SELIM $^{1}$; NABILA OSMAN ${ }^{2}$; AHMED I. AHMED ${ }^{2}$ and SOAD A. NASEF ${ }^{3}$ \\ ${ }^{1}$ Reference Laboratory for Veterinary Quality Control on Poultry Production, Animal \\ Health Research Institute, Luxor, Egypt \\ ${ }^{2}$ Department of Poultry and Rabbit Diseases, Faculty of Veterinary Medicine, South \\ Valley University, 83523, Qena, Egypt \\ ${ }^{3}$ Reference Laboratory for Veterinary Quality Control on Poultry Production, \\ Animal Health Research Institute, 12618, Giza, Egypt
}

Received: 28 June2017; $\quad$ Accepted: 30 July 2017

\begin{abstract}
Avian Infectious bronchitis virus (IBV), a major pathogen of commercial poultry flocks, circulates in the form of multiple ever emerging variants threatening the poultry industry. This study was conducted to survey the presence of IBV from Luxor Governorate during 2015 -2016. Examination of 43 pooled samples including trachea and kidney homogenates by real time RT- PCR for N gene, revealed 35 (81.4\%) out of 43 commercial broiler flocks were positive to IBV. The 400-bp of HVR3 of the S1 gene of ten selected samples were amplified by RT-PCR, sequenced, and aligned for phylogenetic and amino-acid similarity analyses. The ten IBV viruses share from $71 \%$ to $90.8 \%$ homologies between each other but are very different from the vaccinal strains (H120, MA5, M48, 4/91 and CR88) used in Egypt with 62.6 to $84.7 \%$ similarities. Phylogenetic analysis revealed that all the Luxor detected viruses were grouped within the Variant 2 IBV cluster together with the D1456-like Egyptian IBVs but in a different subcluster. Monitoring the emerging IBV variants is extremely important for establishing an effective control strategy for the disease in Luxor and surrounding area.
\end{abstract}

Key words: IBV, S1 Gene, Variant, RT- PCR.

\section{INTRODUCTION}

Avian infectious bronchitis (IB) is an economically important, acute, highly contagious disease of chickens and other fowl, caused by the avian coronavirus infectious bronchitis virus (IBV). Clinically, the disease causes respiratory distress, drop in egg production and quality in layers. Some strains of IBV are associated with nephritis (Cavanagh, 2003; Jackwood and de Wit, 2013). IBV is an enveloped, single-stranded, positive sense RNA, belonging to the genus Gammacoronavirus, subfamily Coronavirinae, family Coronaviridae, order Nidovirales. It has a 27 to $28 \mathrm{~kb}$ genome encoding four structural proteins, spike (S), membrane (M), envelope (E), and nucleocapsid (N) (Perlman et al., 2008; Gelb, 2013). Since the N gene is highly conserved even among IBV isolates of different serotypes and is abundant in infected cells (Williams et al., 1992; Spencer and Hiscox, 2006), it is often the target for nucleic acid based virus identification in diagnostic laboratories.

Corresponding author: Dr. MOHAMED SELIM

E-mail address: mo7amed.sm@gmail.com

Present address: Reference Laboratory for Veterinary Quality Control on Poultry Production, Animal Health Research Institute, Luxor, Egypt
The spike (S) proteinisa major structural protein of IBV, and it is post-translationally cleaved into aminoterminal S1 and carboxy-terminal S2 (Cavanagh, 2007). S1 mediates virion attachment to IBV host cells and is responsible for the induction of neutralizing and serotype-specific antibodies (Casais et al., 2003). The spike protein of IBV has an enormous capacity to change both by spontaneous mutation and by genetic recombination (Cavanagh \& Gelb, 2008) resulting in the emergence of new variant serotypes and genotypes. Mutations occur frequently in hyper variable regions of the $\mathrm{S} 1$ subunit of the spike (S) glycoprotein gene. Hence, the evolutionary characterization of IBV is mainly based on the analysis of the variable $\mathrm{S} 1$ gene or the expressed S1 protein (Lee et al., 2003; Gelb et al., 2005).

Different IBV variants are distributed globally. Some of these variants are endemic only in particular regions, while others circulate worldwide (de Wit et al., 2011). The phylogenetic analysis of currently available S1 gene sequences has identified 6 IBV genotypes comprising 32 viral lineages (Valastro et al., 2016). Genotyping of Egyptian IBVs showed two distinct phylogenetic groups: the classic group resembling the GI-1 genotype (vaccine strains) and the variant group (field strains) of the GI-23 
genotype. The variant genotype was divided into two distinct subgroups (Egy/var I and Egy/var II) resembling the Israeli variants IS/1494 and IS885 strain, respectively (Zanaty et al., 2016a). The aim of this study is to provide information on the molecular characteristics and the phylogenetic relationship of IBV strains in Luxor in comparison to other strains reported in Egypt.

\section{MATERIALS AND METHODS}

\section{Study population}

Forty-three commercial broiler flocks of various ages (18-35 days) were selected from different regions of Luxor governorate, during 2015 and 2016. The examined flocks were showing clinical signs of respiratory and/or nephropathogenic disease. Most Flocks analyzed in this study had been previously vaccinated against IBV with one or more of these vaccines H120, H120-D274 and CR 88121 as shown in (Table 1).

\section{Sample collection}

Four or five chickens either live or dead showing mild to severe respiratory signs and/ or nephropathogenic lesions were selected from each flock. The clinical signs and pathologic findings were recorded. Tissue samples from trachea and kidneys were taken for RT-PCR analysis.

Real time RT-PCR for nucleocapsid gene detection

RNA was extracted from the supernatants of $10 \% \mathrm{w} / \mathrm{v}$ tissue homogenates using QIA amp Viral RNA Mini Kit (Qiagen Inc. Valencia CA) according to the manufacturer's instructions.

The primers and probe specific for IBV are given in Table (2). A standardized Taq Man real-time RTPCR reaction consisted of a total volume of $25 \mu \mathrm{l}$ reaction mixture containing $12.5 \mu l 2 \mathrm{x}$ Quanti Tect Probe RT-PCR Master Mix, $0.5 \mu l$ forward primer, $0.5 \mu l$ reverse primer, $0.125 \mu l$ probe, $5.25 \mu l$ RNasefree water, and $6 \mu l$ template RNA.

Reverse transcription and generation of complementary DNA (cDNA) was performed in onestep using MX3005P machine (Agilent). As per the manufacturer's instructions, cDNA was synthesized at $50{ }^{\circ} \mathrm{C}$ for $30 \mathrm{~min}$, primary denaturation at $95{ }^{\circ} \mathrm{C}$ for $15 \mathrm{~min}$ and amplification was performed for 40 cycles of secondary denaturation at $95{ }^{\circ} \mathrm{C}$ for 15 secs and annealing and extension at $60{ }^{\circ} \mathrm{C}$ for $45 \mathrm{sec}$.

Table 1: The sample data of IBV strains used for partial S1 gene characterization in this study.

\begin{tabular}{|c|c|c|c|c|c|c|}
\hline $\begin{array}{c}\text { Isolate } \\
\text { no. }\end{array}$ & Sequence ID & $\begin{array}{l}\text { Age } \\
\text { (day) }\end{array}$ & $\begin{array}{c}\text { Time of } \\
\text { vaccination, } d, \text { and } \\
\text { (virus vaccine) }\end{array}$ & $\begin{array}{l}\text { Collection } \\
\text { date }\end{array}$ & Locality & $\begin{array}{c}\text { Gen Bank } \\
\text { accession no. }\end{array}$ \\
\hline 1 & $\begin{array}{c}\text { IBV/EG/LUXO } \\
\text { R-1-2016 }\end{array}$ & 23 & 1 (H120) & Jan. 2016 & $\begin{array}{l}\text { Luxor- } \\
\text { Armant }\end{array}$ & MF114201 \\
\hline 2 & $\begin{array}{c}\text { IBV/EG/LUXO } \\
\text { R-18-2016 }\end{array}$ & 22 & $\begin{array}{c}1 \& 14(\mathrm{H} 120- \\
\text { D274) }\end{array}$ & Jan. 2016 & $\begin{array}{l}\text { Luxor- } \\
\text { Armant }\end{array}$ & MF114202 \\
\hline 3 & $\begin{array}{c}\text { IBV/EG/LUXO } \\
\text { R-24-2016 }\end{array}$ & 27 & 1 (H120-D274) & Feb. 2016 & $\begin{array}{l}\text { Luxor - } \\
\text { Qurna }\end{array}$ & MF114203 \\
\hline 4 & $\begin{array}{c}\text { IBV/EG/LUXO } \\
\text { R-25-2016 }\end{array}$ & 24 & 14 (H120-D274) & Feb. 2016 & $\begin{array}{l}\text { Luxor - } \\
\text { Qurna }\end{array}$ & MF114204 \\
\hline 5 & $\begin{array}{c}\text { IBV/EG/LUXO } \\
\text { R-28-2015 }\end{array}$ & 24 & $\begin{array}{c}1(\mathrm{H} 120) \\
14(\mathrm{CR} 88121)\end{array}$ & Dec. 2015 & $\begin{array}{l}\text { Luxor - } \\
\text { Esna }\end{array}$ & MF114205 \\
\hline 6 & $\begin{array}{c}\text { IBV/EG/LUXO } \\
\text { R-29-2015 }\end{array}$ & 18 & $7 \& 15$ (H120) & Dec. 2015 & $\begin{array}{l}\text { Luxor - } \\
\text { Esna }\end{array}$ & MF114206 \\
\hline 7 & $\begin{array}{c}\text { IBV/EG/LUXO } \\
\text { R-31-2015 }\end{array}$ & 24 & 7 (H120) & Dec. 2015 & $\begin{array}{l}\text { Luxor - } \\
\text { Esna }\end{array}$ & MF114207 \\
\hline 8 & $\begin{array}{c}\text { IBV/EG/LUXO } \\
\text { R-32-2015 }\end{array}$ & 26 & $\begin{array}{c}3 \text { (H120-D274) } \\
6(\mathrm{H} 120)\end{array}$ & Dec. 2015 & $\begin{array}{l}\text { Luxor - } \\
\text { Esna }\end{array}$ & MF114208 \\
\hline 9 & $\begin{array}{c}\text { IBV/EG/LUXO } \\
\text { R-35-2015 }\end{array}$ & 35 & 2 (H120-D274) & Nov. 2015 & $\begin{array}{l}\text { Luxor- El } \\
\text { Bayadeya }\end{array}$ & MF114209 \\
\hline 10 & $\begin{array}{c}\text { IBV/EG/LUXO } \\
\text { R-38-2016 }\end{array}$ & 28 & 7 (H 120) & Feb. 2016 & $\begin{array}{l}\text { Luxor - El- } \\
\text { Tod }\end{array}$ & MF114210 \\
\hline
\end{tabular}


Table 2: Primers and probes used in the study.

\begin{tabular}{|c|c|c|c|c|c|c|}
\hline Primers & Source & Sequence $5^{\prime}-3^{\prime}$ & $\begin{array}{l}\text { Product } \\
\text { size (bp) }\end{array}$ & $\begin{array}{c}\text { Target } \\
\text { region }\end{array}$ & Location & Reference \\
\hline AIBV-fr & \multirow{5}{*}{$\begin{array}{l}\text { Metabion } \\
\text { (Germany) }\end{array}$} & ATGCTCAACCTTGTCCCTAGCA & \multirow[b]{3}{*}{$130 \mathrm{bp}$} & \multirow[b]{3}{*}{$\mathrm{N}$ gene } & $811-832$ & \multirow{3}{*}{$\begin{array}{l}\text { Meir } \text { et } \\
\quad \text { al. } \\
(2010)\end{array}$} \\
\hline AIBV-as & & TCAA-ACTGCGGATCA-TCACGT & & & 921-941 & \\
\hline AIBV-TM & & $\begin{array}{c}\text { (FAM- } \\
\text { TTGGAAGTAGAGTGACGCCCAA } \\
\text { ACTTCA-TAMRA) }\end{array}$ & & & $848-875$ & \\
\hline IBV-S1-F & & CAC TGG TAA TTT TTC AGA TGG & \multirow[b]{2}{*}{$400 \mathrm{bp}$} & \multirow[b]{2}{*}{ S1 gene } & $729-749$ & \multirow{2}{*}{$\begin{array}{l}\text { Adzhar } \\
\text { et al. } \\
(1997)\end{array}$} \\
\hline IBV-S1-R & & C AGA TTG CTT ACA ACC ACC & & & $1093-1111$ & \\
\hline
\end{tabular}

RT-PCR for S1 gene detection and DNA sequencing

The cDNA of IBV generated from twelve samples found positive by RRT-PCR with high $C_{T}$ values were sent to RLQP, Animal Health Research institute, Egypt for partial sequencing of S1 gene. HVR 3of the S1 gene was amplified using Qiagen one step RTPCR Kit (Qiagen Inc. Valencia CA) and the primers given in Table (2) for performing one step RT-PCR using Thermocycler (T3Biometra, Germany).

The amplicons of $400 \mathrm{bp}$ in size were excised and purifid from gel using the QIA quick gel extraction kit (Qiagen Inc. Valencia CA). The purified RT-PCR products were sequenced using Bigdye Terminator V3.1 cycle sequencing kit (PerkinElmer, Foster City, CA) and Applied Biosystems 3130 genetic analyzer (ABI, USA).

\section{Sequence and Phylogenetic analysis}

Nucleotide S1 sequence data were edited and assembled using Bio Edit Software version 7.2.6. The sequences were aligned and blasted with the published sequences of various IBV strains. CLUSTAL W of Meg Align software was used for HVR3 deduced amino acids comparative analysis, and a phylogenetic tree of the amino acid sequences was constructed using MEGA 7 software with the neighbor-joining method and a consensus of 1000 bootstrap replicates (Kumar et al., 2016). Sequences generated in this study were submitted to the Gen Bank database with accession numbers showed in Table (1).

\section{RESULTS}

Clinical signs and gross pathology

The clinical examination of the investigated flocks revealed general signs of illness, respiratory signs and renal problems in some flocks. The respiratory signs ranged from mild to severe, gasping, sneezing, rales and coughing. Mortality rates ranging from 5-10\%. At necropsy, the main lesions found were tracheitis, lung congestion, air-sacculitis. Some flocks frequently showed mucous or caseated material in trachea and bronchi. Pale or congested and enlarged kidneys with slight to moderate distention of the ureters with urates were also seen.

\section{Real time RT-PCR for screening of samples for IBV}

Tissue homogenates of trachea and/or kidney from each flock were tested with real-time RT-PCR for IBV, whereas 35 samples of the 43 flocks showed positive results for IBV.

\section{RT-PCR for S1 gene detection}

From the twelve samples, 11 samples showed positive result for RT-PCR for S1 gene and one sample was negative. The S1 gene specific primers amplified approximately $400 \mathrm{bp}$ products (a $393 \mathrm{bp}$ PCR product from nucleotide positions 928 to 1320 in the IBV $\mathrm{S} 1$ sequence produced by conventional PCR), which were sequenced and compared to reference and other IBV strains (Fig.1).One sample didn't align correctly and was excluded and the ten samples were genotyped as IS/1494/06 Like.

Partial IBV S1 sequence and Phylogenetic analysis Analysis of the partial S1 sequences derived from the obtained samples identified that all the sequences were related $(71.8 \%-90.1 \%)$ to the variant-2 IS/1494/06 (GI-23) and (74.8\%-94.7\%) to Eg\12120S\2012 previously identified and reported in Egypt (Table 3). The IBV identified in this study also showed similarity to IS/885/00 (71\%-92.4\%).

Sequence similarities varied among the ten detected viruses under the study. Amino acid identities of the characterized strains ranged from (67.2- 90.8\%) to each other, $(65.6-84.7 \%)$ to $4 / 91$ vaccinal strains of IBV and (62.6-79.4\%) to H120 and MA5. IBV/EG/LUXOR-38-2016 had the highest derived amino acid similarity $(79.4 \%)$ to the H120 and MA5 vaccine strains, while IBV/EG/LUXOR-24-2016 had the lowest similarity $(62.6 \%)$ with them.

Phylogenetic analysis, shown in Fig.2, revealed that all the Luxor detected viruses grouped within the D1456 like Egyptian IBV viruses within the Variant 2 IBV cluster but in a different subcluster and none of them is a vaccinal strain. Also, the ten detected viruses separated: 9 viruses belonged to a monophyletic group with the IBV/KFS/2016 previously isolated in Kafrelsheikh governorate while the IBV/EG/LUXOR-38-2016 sat on a separate branch. 
Table 3: Amino acid identities of the $S 1$ partial sequence of the ten IBV strains in this study with other Egyptian strains, reference strains and vaccinal strains used in Luxor.

\begin{tabular}{|c|c|c|c|c|c|c|c|c|c|c|c|c|c|c|c|c|c|c|c|c|}
\hline & & 1 & 2 & 3 & 4 & 5 & 6 & 7 & 8 & 9 & 10 & 11 & 12 & 13 & 14 & 15 & 16 & 17 & 18 & 19 \\
\hline 1 & $E g \backslash 12120 S \backslash 2012$ & & 93.9 & 96.2 & 83.2 & 87.0 & 83.2 & 83.2 & 84.7 & 86.3 & 88.5 & 87.0 & 74.8 & 74.8 & 92.4 & 79.4 & 84.0 & 79.4 & 87.8 & 94.7 \\
\hline 2 & IS \1494\06 & & & 93.9 & 81.7 & 87.8 & 81.7 & 81.7 & 84.0 & 87.0 & 85.5 & 84.0 & 73.3 & 71.8 & 87.8 & 75.6 & 77.9 & 74.8 & 81.7 & 90.1 \\
\hline 3 & IS \885 & & & & 82.4 & 87.0 & 82.4 & 82.4 & 84.7 & 86.3 & 86.3 & 84.0 & 72.5 & 71.0 & 91.6 & 75.6 & 80.2 & 78.6 & 85.5 & 92.4 \\
\hline 4 & $\mathrm{H} 120$ & & & & & 80.9 & 100.0 & 97.7 & 79.4 & 80.9 & 77.1 & 72.5 & 62.6 & 64.1 & 76.3 & 68.7 & 68.7 & 65.6 & 72.5 & 79.4 \\
\hline 5 & CR88121 & & & & & & 80.9 & 80.9 & 84.7 & 96.2 & 84.0 & 77.1 & 66.4 & 66.4 & 81.7 & 74.0 & 72.5 & 71.8 & 77.1 & 83.2 \\
\hline 6 & Ma5 & & & & & & & 97.7 & 79.4 & 80.9 & 77.1 & 72.5 & 62.6 & 64.1 & 76.3 & 68.7 & 68.7 & 65.6 & 72.5 & 79.4 \\
\hline 7 & M41 & & & & & & & & 79.4 & 80.2 & 76.3 & 72.5 & 62.6 & 64.1 & 76.3 & 67.9 & 68.7 & 65.6 & 72.5 & 79.4 \\
\hline 8 & D274 & & & & & & & & & 82.4 & 80.2 & 73.3 & 64.1 & 62.6 & 78.6 & 71.0 & 69.5 & 68.7 & 72.5 & 80.2 \\
\hline 9 & $4 \backslash 91$ & & & & & & & & & & 84.7 & 76.3 & 65.6 & 65.6 & 80.9 & 74.8 & 71.8 & 72.5 & 76.3 & 82.4 \\
\hline & IBV/EG/LUXOR-1-2016 & & & & & & & & & & & 79.4 & 70.2 & 71.0 & 89.3 & 85.5 & 77.9 & 79.4 & 80.9 & 87.0 \\
\hline & 1 IBV/EG/LUXOR-18-2016 & & & & & & & & & & & & 80.2 & 82.4 & 85.5 & 73.3 & 86.3 & 77.1 & 83.2 & 85.5 \\
\hline & IBV/EG/LUXOR-24-2016 & & & & & & & & & & & & & 82.4 & 74.0 & 67.2 & 77.9 & 70.2 & 71.8 & 75.6 \\
\hline & 3 IBV/EG/LUXOR-25-2016 & & & & & & & & & & & & & & 75.6 & 67.9 & 78.6 & 72.5 & 71.0 & 74.0 \\
\hline & 4 IBV/EG/LUXOR-28-2015 & & & & & & & & & & & & & & & 79.4 & 85.5 & 84.0 & 86.3 & 90.8 \\
\hline & IBV/EG/LUXOR-29-2015 & & & & & & & & & & & & & & & & 77.1 & 81.7 & 73.3 & 79.4 \\
\hline & 5 IBV/EG/LUXOR-31-2015 & & & & & & & & & & & & & & & & & 80.2 & 83.2 & 83.2 \\
\hline & 7 IBV/EG/LUXOR-32-2015 & & & & & & & & & & & & & & & & & & 79.4 & 78.6 \\
\hline & 3 IBV/EG/LUXOR-35-2015 & & & & & & & & & & & & & & & & & & & 87.8 \\
\hline 19 & IBV/EG/LUXOR-38-2016 & & & & & & & & & & & & & & & & & & & \\
\hline
\end{tabular}

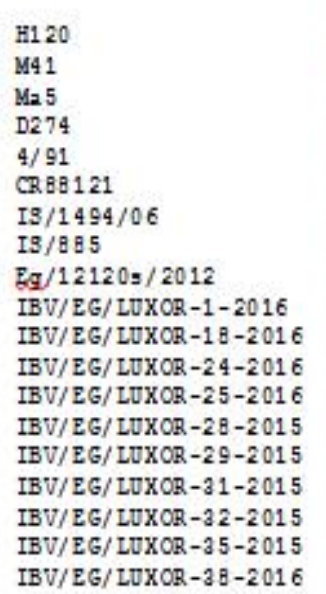

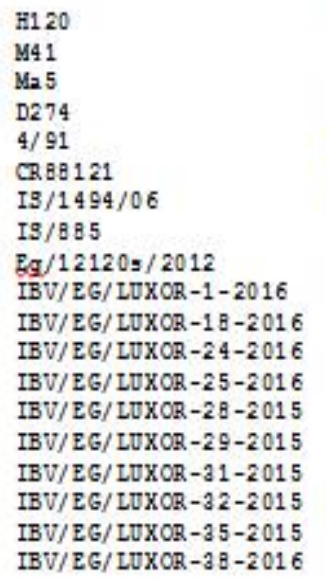

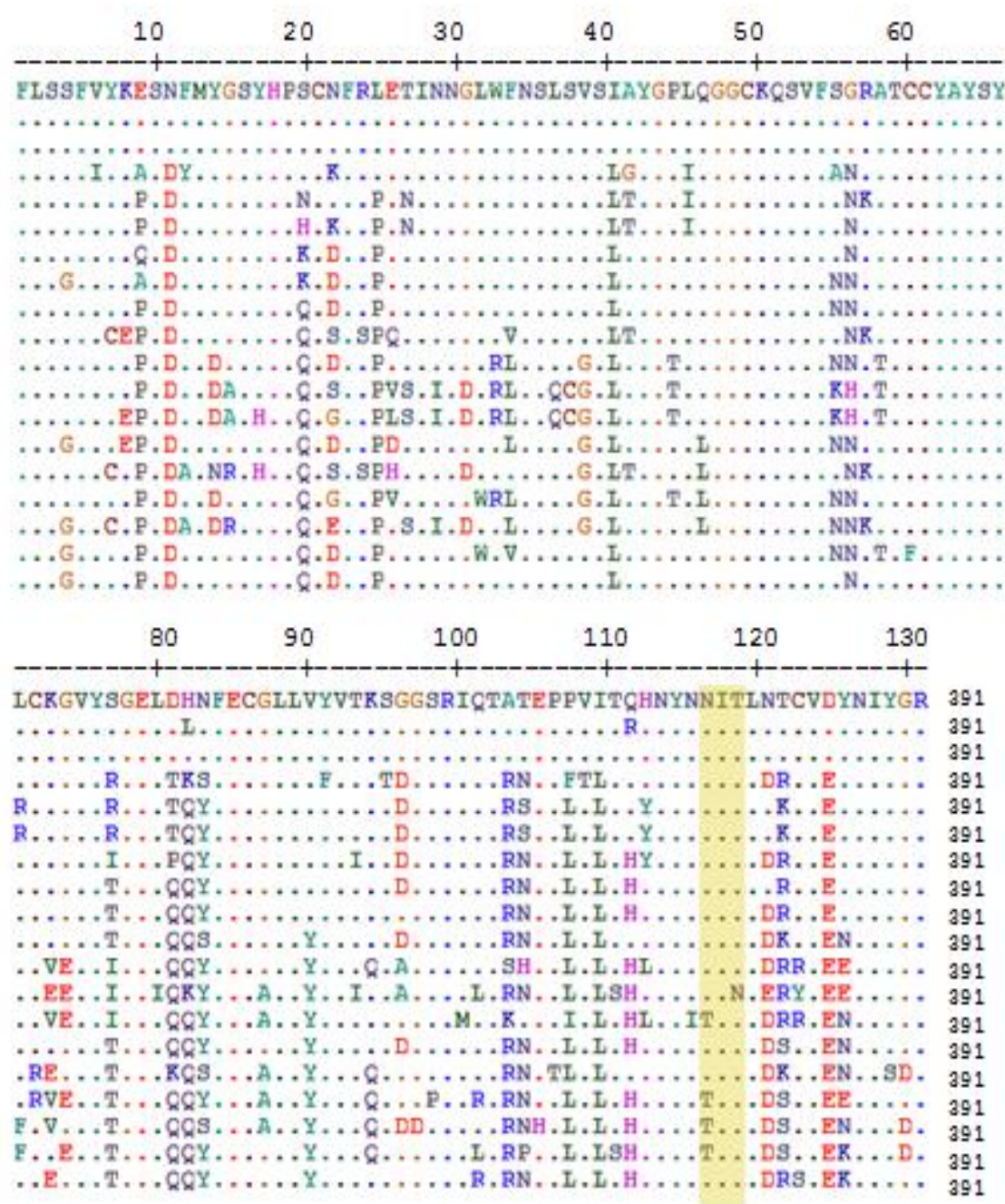

Fig. (1) Multiple sequence alignment of partial amino acid S1 sequences of the obtained IBV strains (nucleotides $1-391$ ) with IBV reference and vaccinal strains. Dots indicate conserved amino acids. Potential glycosylation sites are highlighted. 


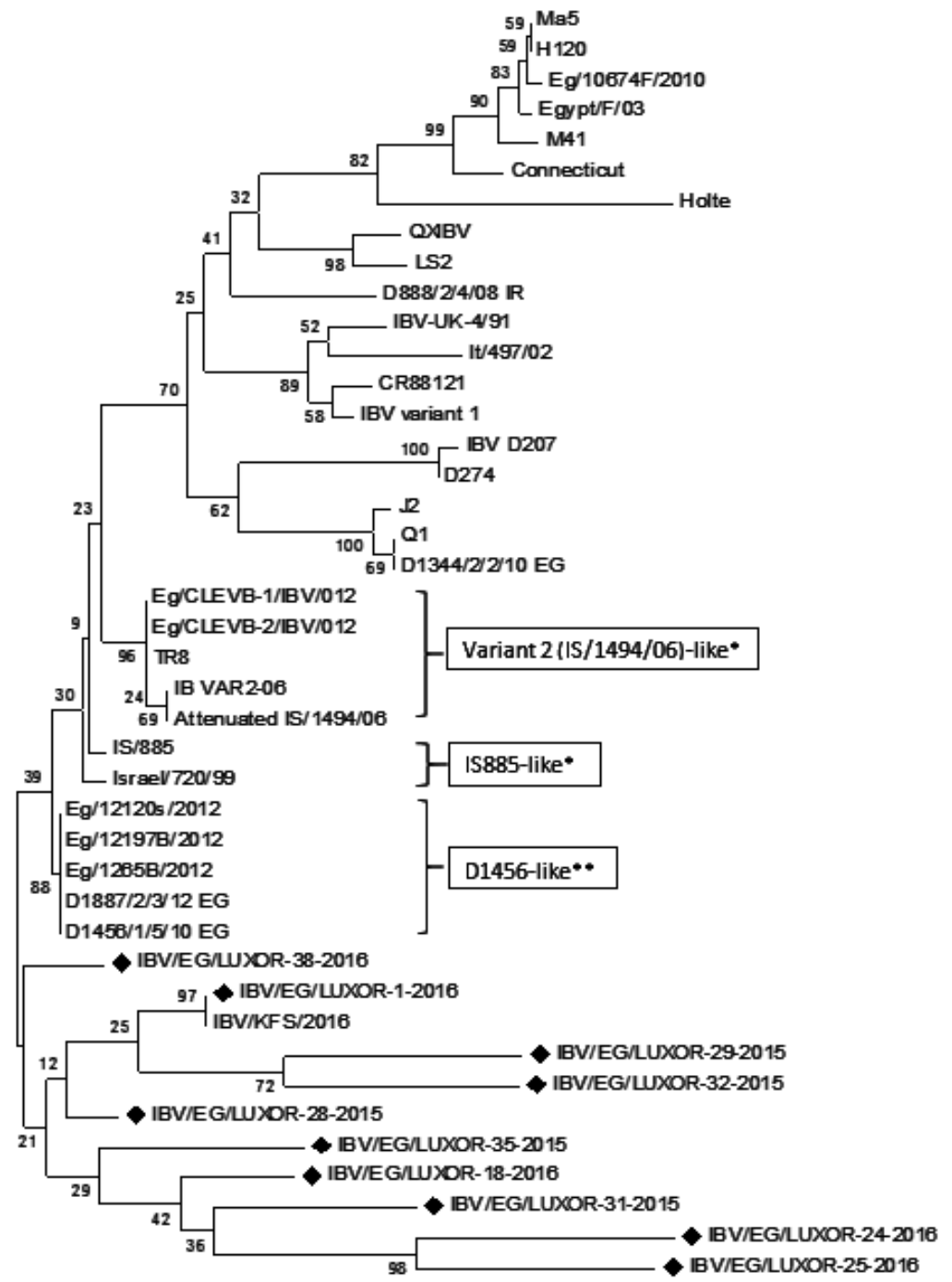

Fig. (2) Phylogenetic tree based on the amino acid sequence of HVR3 of the S1 gene, showing the relationship between the ten IBVs in this study, other Egyptian isolates, vaccinal strains and other reference IBV strains. indicates viruses detected in the current study. *indicates the grouping of (Ganapathy et al., 2015) and **(Kiss et al., 2016). The sequences obtained from Gen Bank.

\section{DISCUSSION}

A large number of IBV variants exist worldwide due to mutations, insertions/deletions, and recombination events that affect the viral genome, having an economic impact on poultry production globally (Jackwood et al., 2005; de Wit et al., 2011). These genetic changes result in antigenic variations between different IBV strains making the control of IBV an extremely challenging task.

In this study, IBV was detected in $81.4 \%$ of the examined flocks and all of the flock-derived sequences were genotyped as IS/1494/06 like. Results obtained from field surveys for the detection of IBV in chickens in Egypt showed about $64 \%$ positive for IBV (Selim et al., 2013).
The clinical examination of the examined flocks under this study showed mild to severe respiratory signs including coughing, sneezing, gasping and tracheal rales. Some examined flocks showed renal signs in the form of wet droppings and increased water intake. These findings were agreed with these observed by Sediek and Awad (2014). The predominant necropsy findings included caseous material, exudate and congestions in the trachea, congestion of the lungs accompanied by air sacculitis which are consistent with previous findings reported from the field (Jackwood\& de Wit, 2013) and from experimental infections (Zanaty et al., 2016b). Kidneys were affected in some flocks.

Reverse transcriptase-polymerase chain reaction (RTPCR) assays are rapid, specific, and accurate, and when targeting the viral S1 gene, the amplification products can be used for further classification of the virus (Lee et al., 2000; Gelb et al., 2005). 
Nevertheless, compared to virus isolation, these assays may lack sensitivity when used directly from clinical specimens (Kwon et al., 1993). In this study RT-PCR was used directly from clinical specimens without previous isolation depending on the results obtained by Grgic et al. (2008) who comparedthe sequences of the viruses before and after their passage in embryonated eggs and chickens and found that they all were $100 \%$ identical. A similar observation was also reported by Naqi et al. (2003).

The partial S1 gene sequence analysis indicated that none of the detected viruses was of vaccine origin and all samples were distantly related to the Variant 2 IS/1494/06. These sequence results are similar to the results obtained by Kiss et al. (2016) from submissions from 2010-2015 and to Eg/1265B/2012, $\mathrm{Eg} / 12197 \mathrm{~B} / 2012$, and $\mathrm{Eg} / 12120 \mathrm{~s} / 2012$ previously isolated in Egypt.

IBVs have been detected in Egypt for more than 60 years, including Massachusetts, D274, 4/91 and variants related to IS/1494 and IS/885 (Susan et al., 2010; Abdel-Moneim et al., 2012). The phylogenetic analysis showed that the flocks-derived sequences in this study were distantly related to IBV variant-2 IS/1494/06 and Egy/12120s/2012. Although clustered in the same clade with these isolates, they aligned in a different subcluster suggesting that IBV circulating in this area is undergoing evolution. No data are available for comparison between the viruses detected in this study and other IBVs from the same area since the IBV (IBV-EG/1290B) isolated by Selim et al. (2013) didn't align with the viruses of this study. Further studies targeting the whole S1 gene sequence are needed to support this suggestion.

In Luxor, chickens are routinely vaccinated with multiple IBV vaccines including mass serotypes as H120, MA5, M48 and recently the variant serotypes 4/91 and CR88. Phylogeny results showed that viruses detected in this study are different from IBV vaccine strains currently applied to poultry flocks in Luxor. Challenge studies revealed that the H120 vaccine provides poor protection (25\%) against Variant 2 (Gelb et al., 2005). Awad et al. (2015) showed that administering combined live H120 and CR88 vaccines simultaneously at day-old followed by CR88 vaccine at 14 days-old gave more than $80 \%$ tracheal ciliary protection from both of the Middle East IS/885/00-like and IS/1494/06-like isolates.

The detection of IBV in these flocks and the development of the clinical signs of the disease in spite of the use of vaccination, suggests that either the current IBV vaccines or the vaccination regimens applied are not adequate for protection. These speculations need to be determined in future studies.

In conclusion, IBVs related to those circulating in Egypt including various governorates were identified in chickens from Luxor broiler flocks. Clinical signs and pathologic lesions were mainly confined to the respiratory and urinary tracts of infected chickens. The results indicate that IBV circulating in Luxor is very different from the used vaccinal strains. Vaccination programs currently applied to commercial flocks should be assessed in future studies.

\section{ACKNOWLEDGMENTS}

The authors would like to thank Dr. Ali Zanaty, Gene analysis unit, RLQP, Animal Health Research Institute, Giza, for his technical assistance through the sequence analysis.

\section{REFERENCES}

Abdel-Moneim, A.S.; Afifi, M.A. and El-Kady, M.F. (2012): Emergence of a novel genotype of avian infectious bronchitis virus in Egypt. Arch Virol. 157(12), 2453-2457.

Adzhar, A.; Gough, R.E.; Haydon, D.; Shaw, K.; Britton, P. and Cavanagh, D. (1997): Molecular analysis of the 793/B serotype of infectious bronchitis virus in Great Britain. Avian Pathol. 26: 625-640

Awad, F.; Forrester, A.; Baylis, M.; Lemiere, S. and Ganapathy, K. (2015): Protection conferred by live infectious bronchitis vaccine viruses against variant Middle East IS/885/00-like and IS/1494/06-like isolates in commercial broiler chicks. Vet. Rec. Open, 2(2), e000111.

Casais, R.; Dove, B.; Cavanagh, D. and Britton, P. (2003): Recombinant avian infectious bronchitis virus expressing a heterologous spike gene demonstrates that the spike protein is a determinant of cell tropism. $J$. Virol.77(16), 9084-9089.

Cavanagh, D. (2003): Severe acute respiratory syndrome vaccine development: experiences of vaccination against avian infectious bronchitis coronavirus. Avian Pathol.32(6), 567-582.

Cavanagh, D. (2007): Coronavirus avian infectious bronchitis virus. Vet. Res.38(2), 281-297.

Cavanagh, D. and Gelb, J. (2008): Infectious bronchitis. In A. M. F. Y.M. Saif J.R. Glisson, L.R. McDougald, L.K. Nolan and D.E. Swayne (Ed.), Diseases of Poultry 12th ed. (pp. 117-135). Ames, Iowa, USA: Blackwell Publishing Ltd.

de Wit, J.J.; Cook, J.K.A. and van der Heijden, H.M.J.F. (2011): Infectious bronchitis virus variants: a review of the history, current situation and control measures. Avian Pathol. 40(3), 223-235.

Ganapathy, K.; Ball, C. and Forrester, A. (2015): Genotypes of infectious bronchitis viruses 
circulating in the Middle East between 2009 and 2014. Virus Res. 210, 198-204.

Gelb, J. (2013): Avian Infectious Bronchitis. Manual of Diagnostic Tests and Vaccines for Terrestrial Animals (Mammals, Birds and Bees). Volumes 1 \& 2. World Organization for Animal Health, (May), 1-15.

Gelb, J.; Weisman, Y.; Ladman, B.S. and Meir, R. (2005): Gene characteristics and efficacy of vaccination against infectious bronchitis virus field isolates from the United States and Israel (1996 to 2000). Avian Pathol. 34(3), 194-203.

Grgic, H.; Hunter, D.B.; Hunton, P. and Nagy, E. (2008): Pathogenicity of infectious bronchitis virus isolates from Ontario chickens. Can. J. Vet. Res. Can. Rech. Vet. 72(5), 403-410.

Jackwood, M. and de Wit, J.J. (2013): Infectious bronchitis. In D. E. Swayne (Ed.), Diseases of Poultry, 13th ed. (pp. 139-159). Ames, Iowa, USA: John Wiley and Sons, Inc.

Jackwood, M.W.; Hilt, D.A.; Lee, C.W.; Kwon, H.M.; Callison, S.A.; Moore, K.M.;Moscoso, H.;Sellers, H. and Thayer, S. (2005): Data from 11 years of molecular typing infectious bronchitis virus field isolates. Avian Dis. 49(4), 614-618.

Kiss, I.; Mató, T.; Homonnay, Z.; Tatár-Kis, T. and Palya, V. (2016): Successive occurrence of recombinant infectious bronchitis virus strains in restricted area of Middle East. Virus Evol.2(2), vew021.

Kwon, H.M.; Jackwood, M.W. and Gelb, J. (1993): Differentiation of Infectious-Bronchitis Virus Serotypes Using Polymerase Chain-Reaction and Restriction-Fragment-LengthPolymorphism Analysis. Avian Dis.37(1), 194-202.

Kumar, S.; Stecher G. and Tamura, K. (2016): MEGA7: Molecular Evolutionary Genetics Analysis version 7.0 for bigger datasets. Molecular Biology and Evolution 33:18701874.

Lee, C.W., Hilt, D.A. and Jackwood, M.W. (2000): Redesign of primer and application of the reverse transcriptase-polymerase chain reaction and restriction fragment length polymorphism test to the DE072 strain of infectious bronchitis virus. Avian Dis. 44(3), 650-654.

Lee, C.W.; Hilt, D.A. and Jackwood, M.W. (2003): Typing of field isolates of infectious bronchitis virus based on the sequence of the hypervariable region in the $\mathrm{S} 1$ gene. J. Vet. Diagnostic Investig. 15(4), 344-348.

Meir, R.; Maharat, O.; Farnushi, Y. and Simanov, L. (2010): Development of a real-time Taq
Man® RT-PCR assay for the detection of infectious bronchitis virus in chickens, and comparison of RT-PCR and virus isolation. J. Virol. Methods, 163: 190-194.

Naqi, S.; Gay, K.; Patalla, P.; Mondal, S. and Liu, R. (2003): Establishment of persistent avian infectious bronchitis virus infection in antibody-free and antibody-positive chickens. Avian Dis.47(3), 594-601.

Perlman, S.; Gallagher, T. and Snijder, E.J. (2008): Nidoviruses. Washington, DC: ASM Press.

Sediek, M.E. and Awad, A.M. (2014): Pathogenicity Assessment of Seven Variants of Infectious Bronchitis Virus Isolated from Commercial Broiler Chickens during 2013 in Egypt. J. World's Poult. Res. 4(3): 64-74.

Selim, K.; Arafa, A.S.; Hussein, H.A. and El-Sanousi, A.A. (2013): Molecular characterization of infectious bronchitis viruses isolated from broiler and layer chicken farms in Egypt during 2012. International J. Vet. Sc Med., 1(2), 102-108.

Spencer, K.A. and Hiscox, J.A. (2006): Expression and structural analysis of infectious bronchitis virus nucleoprotein. Nidoviruses: Toward Control of Sars and Other Nidovirus Diseases, 581, 133-138.

Susan, S. El-Mahdy; El-Hady, M.M.and Soliman, Y.A. (2010): Isolation and Characterization of Nephropathogenic Strain of Infectious Bronchitis Virus in Egypt. Journal of American Science , 6: $669-675$.

Valastro, V.; Holmes, E.C.; Britton, P.; Fusaro, A.; Jackwood, M.W.; Cattoli, G. and Monne, I. (2016): S1 gene-based phylogeny of infectious bronchitis virus: An attempt to harmonize virus classification. Infection Genetics and Evolution, 39, 349-364.

Williams, A.K.; Li, W.; Sneed, L.W. and Collisson, E.W. (1992): Comparative Analyses of the Nucleocapsid Genes of Several Strains of Infectious-Bronchitis Virus and Other Coronaviruses. Virus Research, 25(3), 213222.

Zanaty, A.; Arafa, A.S.; Hagag, N. and El-Kady, M.F. (2016b): Genotyping and pathotyping of diversified strains of infectious bronchitis viruses circulating in Egypt. World JVirol. 5(3), 125-134.

Zanaty, A.; Naguib, M.M.; El-Husseiny, M.H.; Mady, W.; Hagag, N. and Arafa, A.S. (2016a): The sequence of the full spike $S 1$ glycoprotein of infectious bronchitis virus circulating in Egypt reveals evidence of intra-genotypic recombination. Arch Virol. 161(12), 35833587. 


\section{التوصيف الجيني لفيروسات التهاب الثعب الهوائية المعدي المتحورة المكتثفة

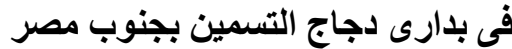

\section{محمد سليم ، نبيلية عثمان ، أحمد إبر/هيم ، سعاد ناصف}

Email: mo7amed.sm@gmail.comAssiut University web-site: www.aun.edu.eg

يعد فيروس التهاب الثعب الهو ائية المعدي أحد العو امل الرئيسية الممرضة لقطعان الدواجن، حيث ينتشر في شكل متغير ات متعددة

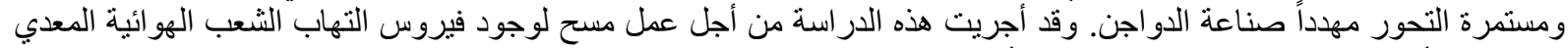

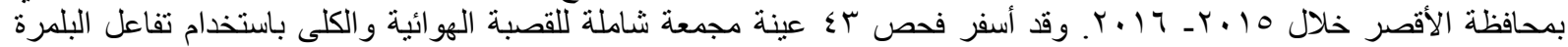

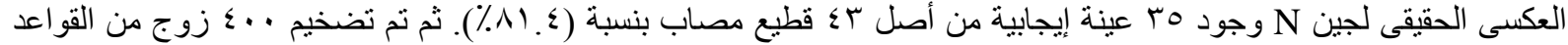

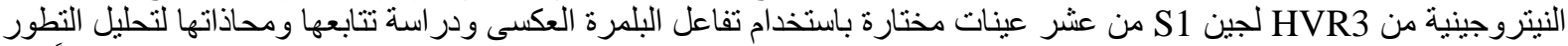

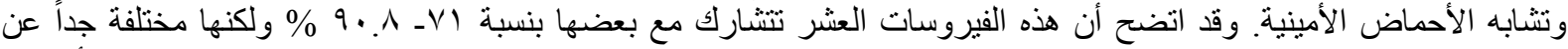

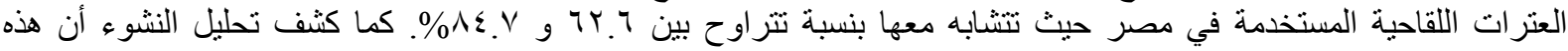

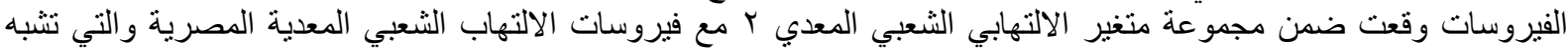

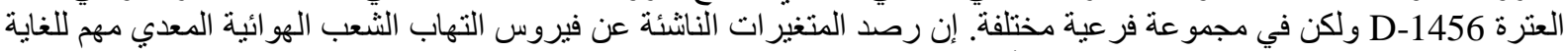

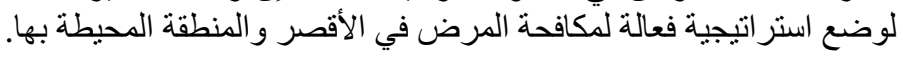

